\title{
HERBAL MANGROVE SEBAGAI SUMBER ANTI BAKTERI Vibrio harveyi PENYEBAB PENYAKIT PADA UDANG WINDU Penaeus monodon
}

\author{
Muliani ${ }^{\#, ~ N u r h i d a y a h, ~ d a n ~ K o k o ~ K u r n i a w a n ~}$ \\ Balai Penelitian dan Pengembangan Budidaya Air Payau \\ (Naskah diterima: 5 Februari 2015; Revisi final: 8 Mei 2015, Disetujui publikasi: 2 September 2015)
}

\begin{abstract}
ABSTRAK
Penelitian ini bertujuan untuk mendapatkan herbal tanaman mangrove sebagai sumber antibakteri $V$. harveyi penyebab penyakit pada udang windu Penaeus monodon. Penelitian dilakukan di Balai Penelitian dan Pengembangan Budidaya Air Payau (BPPBAP), Maros. Mangrove diambil dari lima lokasi yaitu: Kabupaten Maros, Pangkep, Luwu Timur, Takalar, dan Bone. Mangrove yang dikumpulkan diidentifikasi sebelum dikering-anginkan selama dua minggu. Setelah kering dibuat tepung dan diekstrak menggunakan pelarut organik (metanol). Ekstrak metanol dari herbal mangrove diuji bioassay secara kualitatif dan kuantitatif untuk mengetahui aktivitas anti $V$. harveyi menggunakan metode mikrowell plate. Setelah itu, dilakukan uji tantang secara in vitro dengan $V$. harveyi pada konsentrasi yang berbeda dan selanjutnya dilakukan penentuan konsentrasi ambang bawah dan ambang atas yang mematikan terhadap larva udang windu. Hasil penelitian menunjukkan bahwa dari 88 sampel herbal mangrove yang dikumpulkan $58(65,91 \%)$ sampel positif mengandung antibakteri $V$. harveyi, yang terdiri atas: $11(18,96 \%)$ dari Maros, 16 (27,59\%) dari Pangkep, 11 $(18,96 \%)$ dari Luwu Timur, 4 (6,90\%) dari Takalar, dan 16 (27,59\%) dari Bone. Minimum Inhibition Concentration (MIC) terbaik ditunjukkan oleh lima jenis tanaman mangrove yaitu; Sonneratia lanceolata dengan nilai MIC $0,1 \mathrm{mg} / \mathrm{L}$ dan Sonneratia alba, Sonneratia caseolaris, Bruguiera gymnorrhiza, serta Rhizophora mucronata dengan nilai MIC masing-masing $1 \mathrm{mg} / \mathrm{L}$. Hasil uji tantang secara in vitro dengan $V$. harveyi menunjukkan bahwa $S$. alba dan S. caseolaris terbaik menghambat pertumbuhan $V$. harveyi. Konsentrasi $10.000 \mathrm{mg} / \mathrm{L}$ dari ekstrak metanol S. lanceolata, S. alba, S. caseolaris, serta B. gymnorrhiza sudah toksik bagi benur udang windu, dengan mortalitas mencapai $100 \%$ setelah 96 jam.
\end{abstract}

KATA KUNCI: mangrove, herbal, antibakteri, V. harveyi, vibriosis, Penaeus monodon

ABSRTACT: $\quad$ Mangrove herbs as a source of antibacterial $V$. harveyi causes disease in black tiger shrimp Penaeus monodon. By: Muliani, Nurhidayah, and Koko Kurniawan

This experiment was aimed to findout of mangrove herbs as a source of antibacterial $V$. harveyi causes disease in black tiger shrimp Penaeus monodon. The experiment was conducted in several stages, namely: a) collection and identification of mangrove plants, b) preparation and drying plant mangrove; c) preparation of starch; d) extraction and evaporate; e) qualitative bioassay test; f) quantitative bioassay test; g) in vitro test challenged with $V$. harveyi; h) toxicity tests against larvae of tiger shrimp. The result showed that as many as 88 samples of mangrove herbs collected from Maros, Pangkep, Luwu Timur, Takalar, and Bone, 58 (65.91\%) of them positive for antibacterial $\mathrm{V}$. harveyi, which consisted of 11 (18.96\%) samples were from Maros, 16 (27.59\%) samples were from Pangkep, 11 (18.96\%) samples were from Luwu Timur, 4 (6.90\%) samples were from Takalar, and 12 (2.59\%) samples were from Bone. Minimum Inhibition Concentration (MIC) best indicated by four mangrove species namely; Sonneratia lanceolata $0.1 \mathrm{mg} / \mathrm{L}$ and Sonneratia alba, Sonneratia caseolaris, and Bruguiera gymnorrhiza $1 \mathrm{mg} / \mathrm{L}$ respectively. In vitro challenged test result showed that both $S$. alba and $S$. caseolaris were the best bactericidal for $V$. harveyi. The results of toxicity tests showed that the methanol extract of S. lanceolata, S. alba, S. caseolaris, and B. gymnorrhiza are toxit to tiger shrimp larvae at a concentration of 10,000 $\mathrm{mg} / \mathrm{L}$ after 96 hours.

KEYWORDS: $\quad$ mangrove, herbs, antibacterial, V. harveyi, vibriosis, Penaeus monodon

\# Korespondensi: Balai Penelitian dan Pengembangan Budidaya

Air Payau. Jl. Makmur Dg. Sitakka No. 129, Maros 90512,

Sulawesi Selatan, Indonesia. Tel.: + (0411) 371544; 371545

E-mail: litkanta@indosat.net.id 


\section{PENDAHULUAN}

Penyakit vibriosis atau penyakit udang berpendar disebabkan oleh beberapa jenis bakteri vibrio seperti: Vibrio harveyi, Vibrio parahaemolytiucus, Vibrio alginolyticus, Vibrio fischeri. Di antara beberapa jenis vibrio, yang paling berbahaya adalah $V$. harveyi (Kannapiran et al., 2009) dan sampai saat ini penyakit ini masih merupakan kendala utama pada usaha budidaya udang, baik pada panti perbenihan maupun pada tambak pembesaran.

Usaha penanggulangan penyakit vibriosis pada udang dengan memanfaatkan bahan kimia, antibiotik, dan pestisida oleh petambak masih terus terjadi di lapangan, meskipun pemerintah telah melarang keras pemanfaatan bahan-bahan tersebut. Peredaran obat-obatan kimia dan antibiotik di pasaran tidaklah mudah untuk dikendalikan, hal ini dikarenakan masih tingginya permintaan oleh para pengguna. Penggunaan obat-obatan kimia dan antibiotik tidak hanya terjadi di perbenihan tapi juga di pembudidaya. Hal ini tentunya sangat merugikan karena tanpa disadari, penggunaan obat-obatan tersebut justru semakin menambah permasalahan di lapangan akibat efek samping yang ditimbulkan seperti terjadi resistensi bakteri patogen terhadap antibiotik, akumulasi bahan kimia, dan pencemaran pada lingkungan yang semakin memperburuk lingkungan budidaya. Merupakan tanggung jawab kita bersama untuk menghindarkan para petani tambak dari penggunaan obatobatan yang tidak jelas kegunaanya dengan menyediakan alternatif pengganti obat-obatan tersebut yang lebih efisien dan ramah lingkungan.

Penggunaan bahan alam sebagai alternatif pencegahan penyakit di bidang perikanan mulai dikembangkan di antaranya dengan memanfaatkan tanaman mangrove dan asosiasinya (Millon et al., 2012; Howlader et al., 2013; Laith \& Najiah, 2014; Mouafi et al., 2014). Potensi tanaman mangrove dan asosiasinya untuk penanggulangan penyakit pada udang dan ikan telah banyak dilaporkan. Menurut Shamsuddin et al. (2013); Muliani et al. (2014); Ramesh et al. (2014); Babuselvam et al. (2012), melaporkan bahwa beberapa jenis mangrove efektif sebagai anti $V$. harveyi, $V i$ brio vulnificus, Vibrio alginolyticus, Vibrio anginllarum, dan Vibrio lohi pada udang dan anti Bacillus subtilis, Serratia sp., Aeromonas hydrophila, V. harveyi, dan V. parahaemolyticus pada ikan. Pencegahan penyakit vibriosis pada lobster menggunakan herbal mangrove dilaporkan oleh Baskaran \& Mohan (2012). Pemanfaatan mangrove sebagai antibakteri pada udang putih dan ikan hias juga telah dilaporkan (Arivuselvan et al., 2011; Dhayanithi et al., 2013), dan pada ikan mas (Ahilan et al., 2010). Selain sebagai anti bakteri, tanaman herbal mangrove dan asosiasinya juga mulai dikaji sebagai anti WSSV pada udang (Sahu et al., 2012; Chakraborty \& Ghosh, 2013a, 2013b; Chakraborty et al., 2014; Chakraborty \& Ghosh, 2014).

Beberapa tanaman mangrove yang mempunyai nilai ekonomis tinggi dan telah diketahui mengandung bakterisida (Turker et al., 2009; Shelar et al., 2012; Mulyani et al., 2013) di antaranya adalah spesies Rhizophora mucronata (Baskaran \& Mohan, 2012). Hasil penelitian menunjukkan bahwa pada konsentrasi 100 $\mathrm{mg} / \mathrm{L}$ sampai $300 \mathrm{mg} / \mathrm{L}$ ekstrak daun mangrove Rhizophora apiculata mampu menghambat pertumbuhan bakteri $V$. parahaemolyticus. Diameter zona hambatan yang dihasilkan pada konsentrasi $100 \mathrm{mg} / \mathrm{L}$ rata-rata sebesar 6,73 mm; sedangkan pada konsentrasi 200 $\mathrm{mg} / \mathrm{L}$ sebesar 7,17 mm; dan pada konsentrasi 300 $\mathrm{mg} / \mathrm{L}$ sebesar 8,53 mm (Setyaningrum, 2011). Suryati et al. (2007) melaporkan bahwa beberapa jenis mangrove yang dapat mereduksi penyakit pada budidaya udang windu khususnya penyakit vibriosis antara lain: Avicenia alba, Acanthus ilicifolius, Carbera manghas, Clerodendron inerme, Euphatorium inulifolium, Exoecaria agalocha, Osbornia octodonta, dan Soneratia caseolaris. Selain sebagai antibakteri dan anti WSSV, tanaman mangrove juga telah dilaporkan sebagai bahan imunostimulan pada ikan (Govind et al., 2012).

Berdasarkan potensi bahan aktif yang terkandung dalam herbal mangrove tersebut maka dilakukan penelitian yang bertujuan untuk mendapatkan herbal mangrove sebagai sumber antibakteri $V$. harveyi penyebab penyakit pada udang windu dari beberapa lokasi pertambakan di Sulawesi Selatan.

\section{BAHAN DAN METODE}

\section{Pengambilan dan Identifikasi Tanaman Mang- rove}

Tanaman mangrove diambil dari beberapa daerah pertambakan di Sulawesi Selatan yaitu; Kabupaten Maros, Pangkep, Luwu Timur, Bone, Takalar, dan Bone. Bagian tanaman yang diambil meliputi: daun, bunga, buah, tangkai daun, batang, kulit batang, dan akar. Tanaman dimasukkan dalam kantong plastik hitam dan selanjutnya dibawa ke Laboratorium Kesehatan Ikan dan Lingkungan BPPBAP. Identifikasi terhadap tanaman mangrove dilakukan berdasarkan Kitamura et al. (1998) dan Noor et al. (2006).

\section{Preparasi dan Pengeringan Bahan Herbal Mang- rove}

Tanaman mangrove yang sudah dikoleksi, selanjutnya dibersihkan sesuai bagian-bagiannya (daun, bunga, buah, tangkai, daun, batang, kulit batang, dan akar). Daun tanaman yang lebar, buah, bunga, dan kulit batang diiris kecil-kecil, dan dikering-anginkan 
serta diberi kode (nomor secara berurut). Lama pengeringan selama dua minggu atau lebih tergantung kondisi sampel.

\section{Pembuatan Tepung (Simplisia)}

Setelah tanaman herbal kering, selanjutnya dihaluskan menggunakan blender dan diayak menggunakan saringan santan dengan ukuran sekitar $1 \mathrm{~mm}$. Selanjutnya simplisia tersebut disimpan dalam kantong plastik klip dengan pemberian sesuai nomor urut tanaman sampel untuk proses selanjutnya.

\section{Ekstraksi dan Pengkisatan}

Simplisia yang sudah tersedia ditimbang sebanyak $5 \mathrm{~g}$, dimasukkan dalam erlenmeyer volume 100 mL. Selanjutnya ditambahkan larutan methanol 80\% (Shamsuddin et al., 2013) dan diaduk hingga simplisia terendam. Perendaman dilakukan tiga kali selama 24 jam dan setiap 24 jam dilakukan penyaringan atau tergantung tingkat kekeruhan rendaman, namun rendaman sudah terlihat jernih maka perendaman dihentikan. Hal ini dimaksudkan untuk memaksimalkan ekstrak bahan-bahan aktif tanaman oleh metanol. Hasil penyaringan tersebut kemudian ditampung dalam botol sampel dan selanjutnya dikisatkan dengan menggunakan Rotatory evaporator.

\section{Uji Bioassay Secara Kualitatif Ekstrak Mangrove}

Aktivitas antibakteri $V$. harveyi tanaman mangrove dilakukan dengan teknik "High Throughput Screening” (Langfield et al., 2004; Ganju et al., 2008; Karuppusamy \& Rajasekaran, 2009). Ekstrak metanol herbal mangrove ditimbang sebanyak $10 \mathrm{mg}$, selanjutnya dilarutkan dengan $1 \mathrm{~mL}$ DMSO (dimethylsulfoxide) $10 \%$ dalam eppendorf tube volume $1,5 \mathrm{~mL}$ (Kasanah \& Isnansetyo, 2013). Suspensi isolat V. harveyi dengan nomor 275 hasil isolasi dari udang sakit, dikultur dalam erlenmeyer pada suhu ruang dan digoyang. Setelah itu, dilakukan sub-kultur selama empat jam $\left(10^{8} \mathrm{cfu} / \mathrm{mL}\right)$. Hasil sub-kultur tersebut diencerkan hingga diperoleh kepadatan suspensi bakteri V. harveyi $10^{5} \mathrm{cfu} / \mathrm{mL}$ (Kadriah, 2012).

Uji bioassay dilakukan dengan metode mikro-well plate assay yaitu dengan menggunakan mikroplate 96 well (Kasanah \& Isnansetyo, 2013). Setiap sumur plate mikro diisi media Nutrient Broth sebanyak $40 \mu \mathrm{L}$. Pada uji bioassay disertakan kontrol yaitu: 1) kontrol positif (untuk mengetahui pertumbuhan $V$. harveyi); 2) kontrol media (untuk mengetahui ada tidaknya kontaminan selama proses pekerjaan); 3) kontrol pelarut (untuk mengetahui pelarut DMSO 10\% yang digunakan bersifat menghambat $V$. harveyi atau tidak); 4) kontrol antibiotik (untuk mengetahui ekstrak mangrove memiliki aktivitas antibakteri atau tidak). Sebanyak $40 \mu \mathrm{L}$ ekstrak mangrove dimasukkan ke dalam sumur plate mikro sesuai kode dan 20 $\mu \mathrm{L}$ suspensi bakteri $V$. harveyi ditambahkan di dalam campuran sumur mikroplat dengan tiga kali pengulangan, kecuali pada kontrol media. Setiap jenis ekstrak diulang tiga kali. Lama diinkubasi selama 24 jam pada suhu ruang, selanjutnya ditambahkan indikator pertumbuhan sel bakteri yaitu larutan 3-(4,5-dimethylthiazol-2-yl)-2,5-diphenyltetrazolium bromid (MTT) $5 \mathrm{~g} / \mathrm{L}$ (Wang et al., 2010) sebanyak $10 \mu \mathrm{L}$.

\section{Uji Bioassay Secara Kuantitatif Hasil Ekstraksi Bahan Herbal Mangrove}

Uji bioassay secara kuantitatif dilakukan dengan penentuan daya hambat minimum (MIC) dari ekstrak metanol herbal mangrove terhadap $V$. harveyi. Sampel yang memiliki aktivitas antibakteri $V$. harveyi berdasarkan uji biassay secara kualitatif dilanjutkan dengan uji MIC menggunakan metode mikrowell plate dilution assay yaitu dengan menggunakan mikroplate 96 well. (Kasanah \& Isnansetyo, 2013). Pada uji MIC, persiapan ekstrak mangrove dan suspensi bakteri dilakukan sesuai dengan uji bioassay secara kualitatif dan disertakan kontrol. Bila semua kontrol siap, maka pada sumur plate mikro pertama dan ketujuh diisi dengan $100 \mu \mathrm{L}$ ekstrak mangrove, sedangkan pada sumur plate mikro yang lainnya diisi dengan 50 $\mu \mathrm{L}$ akuades. Kemudian dilakukan pengenceran dengan cara sebanyak $50 \mu \mathrm{L}$ ekstrak mangrove dari sumur plate mikro pertama dan sumur plate mikro ketujuh dipindahkan ke sumur plate mikro berikutnya (sumur plate mikro pertama dan kedelapan), selanjutnya dihomogenkan dengan pemipetan berulang. Selanjutnya, sebanyak $50 \mu \mathrm{L}$ larutan ekstrak mangrove dari sumur plate mikro kedua dan kedelapan masing-masing dipindahkan ke sumur plate mikro berikutnya, demikian seterusnya hingga sumur plate mikro terakhir (sumur plate mikro keenam dan 12). Setelah selesai, sebanyak $30 \mu \mathrm{L}$ media NB ditambahkan ke masing-masing sumur plate mikro, baik pada kontrol maupun pada sumur plate mikro yang berisi ekstrak mangrove. Selanjutnya sebanyak $20 \mu \mathrm{L}$ suspensi bakteri $V$. harveyi ditambahkan di dalam campuran sumur plate mikro kecuali pada kontrol media. Plate mikro kemudian diinkubasi selama 24 jam, selanjutnya ditambahkan indikator pertumbuhan sel bakteri (MTT). Jika setelah ditambahkan MTT warna media berubah menjadi ungu, menunjukkan adanya pertumbuhan sel bakteri dengan demikian ekstrak mangrove tidak memiliki aktivitas anti bakteri, dan jika warna media tetap berwarna kuning (seperti sebelum penambahan MTT) menunjukkan bahwa tidak ada pertumbuhan sel bakteri dengan demikian ekstrak mangrove memiliki aktivitas anti bakteri. Konsentrasi ekstrak mangrove terendah tidak terjadi pe- 
rubahan warna (tidak ada pertumbuhan sel bakteri) merupakan nilai MIC (Kasanah \& Isnansetyo, 2013). Data hasil uji bioassay ekstrak mangrove dianalisis secara dekriptif untuk mengetahui nilai MIC dari setiap sampel yang dianalisis.

\section{Uji Tantang Ekstrak Herbal Mangrove Terhadap V. harveyi (Invitro)}

Ekstrak metanol herbal mangrove yang memiliki aktivitas anti $V$. harveyi paling tinggi $(S$. alba, S. caseolaris, S. gulngai, dan B. gymnorrhiza) dibuat larutan stok $100.000 \mathrm{mg} / \mathrm{L}$ dalam larutan DMSO 10\%. Selanjutnya larutan stok tersebut diencerkan sehingga diperoleh konsentrasi yang lebih rendah. Perlakuan yang dicobakan adalah: 0) $1 \mathrm{mg} / \mathrm{L}$, B) $10 \mathrm{mg} / \mathrm{L}$, C) 100 $\mathrm{mg} / \mathrm{L}$, D) $1.000 \mathrm{mg} / \mathrm{L}$, E) $10.000 \mathrm{mg} / \mathrm{L}$, F) kontrol (tanpa pemberian ekstrak mangrove). Masing-masing diulang tiga kali. Ke dalam setiap tabung yang berisi ekstrak mangrove sesuai perlakuan, dimasukkan biakan bakteri $V$. harveyi yang berumur empat jam $\left(10^{8} \mathrm{cfu} / \mathrm{mL}\right)$ sebanyak $100 \mu \mathrm{L}$ sehingga konsentrasi $V$. harveyi dalam tabung adalah $10^{6} \mathrm{cfu} / \mathrm{mL}$. Tabung kultur diinkubasi selama 24 jam pada suhu ruang dengan digoyang. Untuk mengetahui pengaruh pemberian ekstrak herbal mangrove, terhadap pertumbuhan $V$. harveyi maka dilakukan pengamatan menggunakan media TCBS agar. Populasi bakteri dihitung berdasar rumus:

$$
\text { N0, N1 }(\mathrm{CFU} / \mathrm{mL})=\frac{\mathrm{T}}{\mathrm{Q}} \times \frac{1}{\mathrm{~S}} \times \frac{1}{\mathrm{~V}}
$$

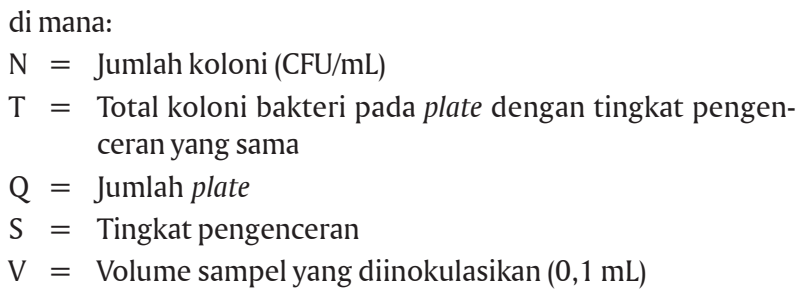

Penentuan Konsentrasi Ambang Bawah dan Ambang Atas Ekstrak Herbal Mangrove terhadap Benur Udang Windu

Sebanyak 60 buah stoples (volume 3 L) digunakan sebagai wadah penelitian. Setiap wadah diisi air laut dengan salinitas 28 ppt sebanyak 1 L. Hewan uji yang digunakan adalah benur udang windu PL-12 dengan kepadatan 30 ekor/wadah. Benur diperoleh dari panti perbenihan skala rumah tangga di Kabupaten Pinrang, Sulawesi Selatan. Benur terlebih dahulu diadaptasikan selama satu minggu hingga kondisinya sehat. Jenis mangrove yang digunakan adalah: A) $S$. alba; B) $S$. caseolaris; C) S. lanceolata; dan D) B. gymnorrhiza. Dosis ekstrak mangrove yang digunakan adalah: A) 0 $\mathrm{mg} / \mathrm{L}$ (kontrol); B) $1 \mathrm{mg} / \mathrm{L}$; C) $10 \mathrm{mg} / \mathrm{L}$; D) $100 \mathrm{mg} / \mathrm{L}$; E) 1.000 mg/L; F) 10.000 mg/L. Pemberian ekstrak man- grove ke dalam stoples dilakukan 30 menit setelah penebaran benur. Mortalitas udang windu diamati setelah 96 jam.

\section{HASIL DAN BAHASAN}

\section{Uji Bioassay Secara Kualitatif}

Sebanyak 88 sampel herbal mangrove yang dikumpulkan dari Kabupaten Maros, Pangkep, Luwu Timur, Takalar, dan Bone, telah diuji bioassay untuk mengetahui aktivitas antibakteri $V$. harveyi. Hasil analisis bioassay menunjukkan bahwa 58 (65,91\%) sampel positif mengandung antibakteri $V$. harveyi, masingmasing terdiri atas $11(20,37 \%)$ sampel berasal dari Kabupaten Maros, 16 (29,63\%) berasal dari Kabupaten Pangkep, 11 (20,37\%) sampel berasal dari Luwu Timur, $4(7,41 \%)$ sampel berasal dari Takalar, dan $16(22,22 \%)$ sampel berasal dari Kabupaten Bone (Tabel 1).

Secara umum, hasil uji bioassay secara kualitatif terhadap ekstrak metanol tanaman herbal mangrove disajikan pada Gambar 1A dan 1B. Pada Gambar 1B terlihat bahwa pada baris D, sumur plate mikro 7, 8, dan 9 setelah ditambah MTT tidak terjadi perubahan warna. Hal ini menunjukkan tidak ada pertumbuhan sel bakteri, yang berarti ekstrak mangrove aktif menghambat $V$. harveyi. Namun, pada baris F sumur plate mikro 10, 11, dan 12 terlihat adanya perubahan warna media dari warna kuning (Gambar 1A) menjadi ungu/hitam (Gambar 1B). Hal ini menunjukkan adanya pertumbuhan sel bakteri, yang berarti ekstrak mangrove tidak aktif menghambat $V$. harveyi.

\section{Uji Bioassay Secara Kuantitatif}

Hasil uji bioassay secara kuantitatif untuk mengetahui MIC ekstrak metanol mangrove terhadap V. harveyi disajikan pada Gambar 2. Pada Gambar 2 terlihat bahwa setelah diinkubasi selama 24 jam (Gambar 2B), MIC ekstrak mangrove bervariasi tergantung jenis, asal, dan bagian tanaman (daun, bunga, buah, kulit batang, dan akar). Hal ini dapat dilihat pada Gambar 2B pada sumur plate mikro1-6 baris E (lingkaran merah) menunjukkan bahwa ekstrak metanol dari kulit batang mangrove, S. caseolaris memiliki nilai MIC sebesar $10 \mathrm{mg} / \mathrm{L}$ yang ditandai tidak adanya perubahan warna media pada sumur plate mikro 1-4 dan perubahan warna media dari kuning (pada Gambar 2A) menjadi warna ungu kehitaman terjadi pada well 5 dan 6 (Gambar 2B) yang berarti, bakteri $V$. harveyi dapat tumbuh pada konsentrasi ekstrak mangrove 0,1 dan $1 \mathrm{mg} / \mathrm{L}$. Sedangkan ekstrak metanol dari akar (jenis mangrove yang sama) dapat dilihat pada Gambar 2B pada well 7-12 baris E (lingkaran putih), memiliki nilai MIC $1 \mathrm{mg} / \mathrm{L}$ yang ditandai tidak adanya perubahan warna media pada well 7-11 dan perubahan warna media dari kuning menja- 
Tabel 1. Hasil uji aktivitas anti $V$. harveyi herbal mangrove yang berasal dari beberapa lokasi Table 1. Anti V. harveyi activity and MIC test result of herbal mangrove from several locations

\begin{tabular}{lccc}
\hline \multicolumn{1}{c}{$\begin{array}{c}\text { Asal } \\
\text { Source }\end{array}$} & $\begin{array}{c}\text { Jumlah sampel } \\
\text { Number of samples }\end{array}$ & $\begin{array}{c}\text { Positif anti } \text {. harveyi } \\
\text { Positive anti } \text { V. harveyi }\end{array}$ & $\begin{array}{c}\text { Negatif anti } \text {. harveyi } \\
\text { Negative anti } \text { V. harveyi }\end{array}$ \\
\hline Maros & 15 & 11 & 4 \\
Pangkep & 27 & 16 & 11 \\
Luwu Timur & 13 & 11 & 2 \\
Takalar & 5 & 4 & 1 \\
Bone & 28 & 16 & 12 \\
\hline Total (Total) & $\mathbf{8 8}$ & $\mathbf{5 8}$ & $\mathbf{3 0}$ \\
\hline
\end{tabular}

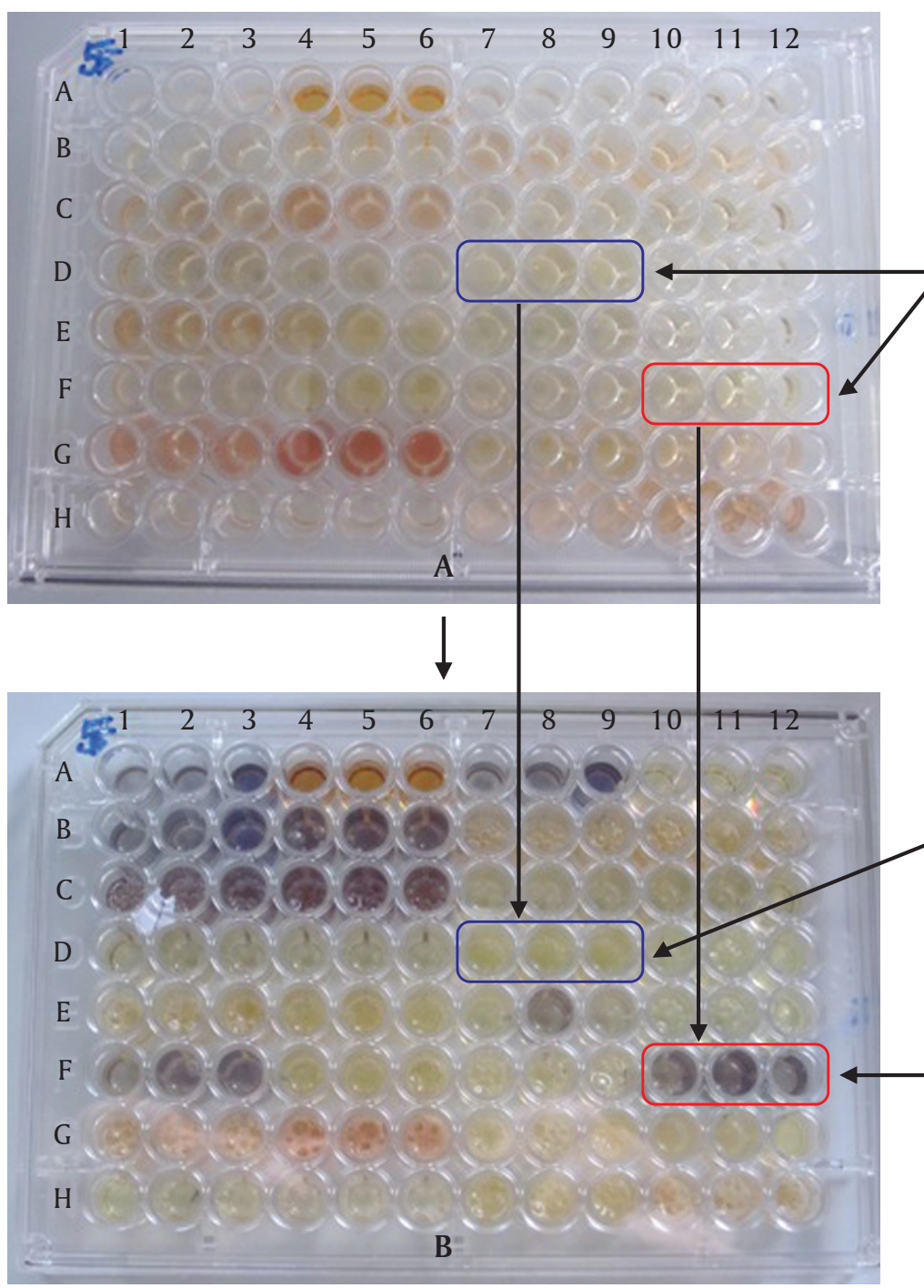

Sebelum penambahan indikator pertumbuhan bakteri (MTT) (Before additing of bacterial growth indicator (MTT))

Keterangan (Note):

Baris A dan well 1-3 = Kontrol positif (bakteri tanpa ekstrak mangrove), Well 4-6 = Kontrol antibiotik, Weel 7-8 = Kontrol pelarut, Well 10-12 = Kontrol media (tanpa bakteri dan ekstrak mangrove) (Line A and well 1-3 = Positive control (bacteria without mangrove extract), Well 4-6 = Antibiotic as control, Well 7-8 = Solvent control, Well 10-12 = Control medium (without bacteria and mangroves extract))

Gambar 1. Uji bioassay secara kualitatif ekstrak metanol herbal mangrove terhadap $V$. harveyi, sebelum penambahan MTT (A), dan setelah penambahan MTT (B)

Figure 1. Qualitative bioassay test of methanol extracted of mangrove herbal on V. harveyi, before MTT added (A) and after MTT added (B)

Sesudah penambahan MTT: Hasil positif (mengandung antibakteri V. harveyi) (After additing of bacterial growth indicator (MTT), the result was positive (containing anti bacteria V. harveyi))

Sesudah penambahan MTT: Hasil positif (mengandung antibakteri V. harveyi) (After additing of bacterial growth indicator (MTT), the result was negative (does not contain anti bacteria V. harveyi) 


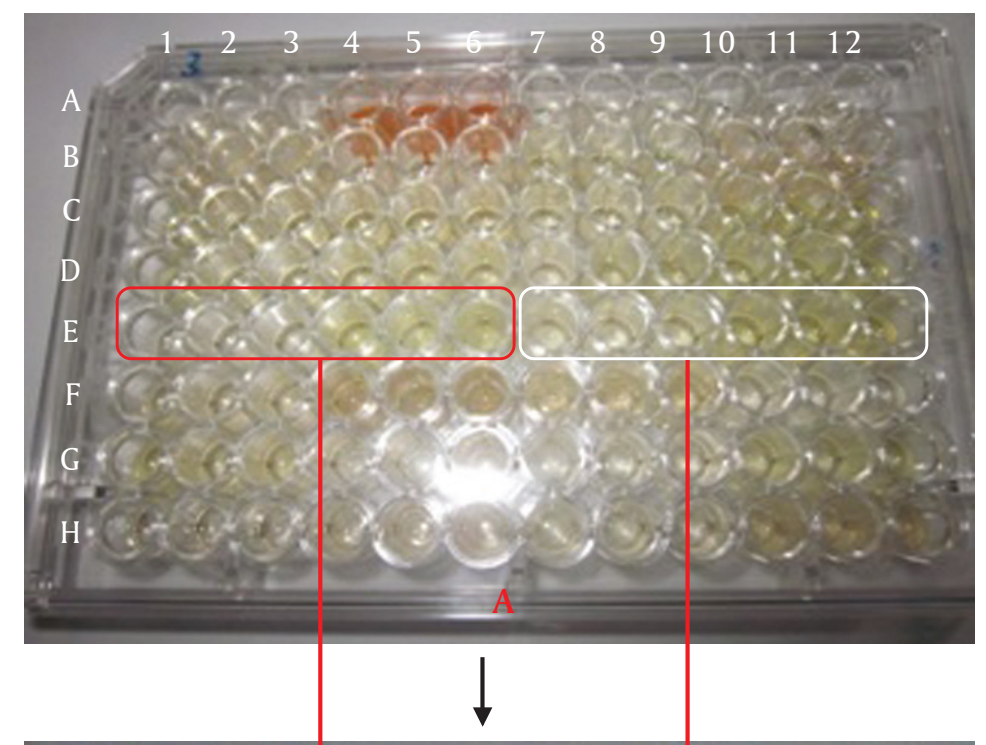

Keterangan (Note):

Baris A dan well 1-3 = Kontrol positif (bakteri tanpa ekstrak mangrove), Well 4-6 = Kontrol antibiotik, Weel 7-8 = Kontrol pelarut, Well 10-12 = Kontrol media (tanpa bakteri dan ekstrak mangrove) (Line A and well 1-3 = Positive control (bacteria without mangrove extract), Well 4-6 = Antibiotic as control, Well 7-8 = Solvent control, Well 10-12 = Control medium (without bacteria and mangroves extract))

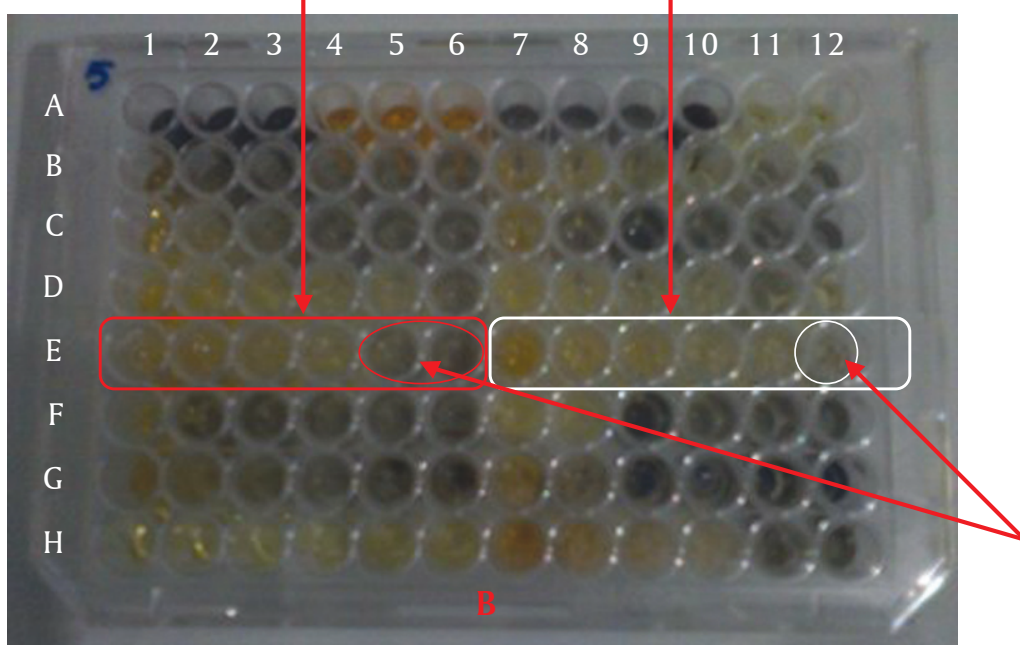

Tidak ada aktivitas antibakteri $V$. harveyi Bacterial activity does not exist

Gambar 2. Uji bioassay secara kuantitatif ekstrak metanol herbal mangrove terhadap $V$. harveyi penyebab penyakit pada udang

Figure 2. Quantitative bioassay test of methanol extracted of mangrove herbal on V. harveyi shrimp disease against

di ungu kehitaman terbentuk pada well 12 yang berarti bakteri $V$. harveyi dapat tumbuh pada konsentrasi ekstrak mangrove $0,1 \mathrm{mg} / \mathrm{L}$.

\section{Hasil Analisis Minimum Inhibition Concentration (MIC)}

Hasil analisis Minimum Inhibition Concentration (MIC) atau konsentrasi minimal yang menghambat (KHM) ekstrak metanol dari tanaman mangrove menunjukkan bahwa MIC paling rendah (daya hambat paling kuat) diperlihatkan oleh jenis mangrove S. lanceolata (Ragavan et al., 2014) yang diambil dari Pangkep yaitu $0,1 \mathrm{mg} / \mathrm{L}$. Seluruh bagian tanaman dianalisis yang meliputi daun, kulit batang, dan tangkai daun memiliki nilai MIC yang sama. Nilai MIC terendah berikutnya yaitu $1 \mathrm{mg} / \mathrm{L}$ diperlihatkan oleh jenis mangrove S. alba dan S. caseolaris dari Maros, B. gymnorrhiza dari Pangkep, Rhizophora mucronata dari Bone. Selanjutnya nilai MIC $10 \mathrm{mg} / \mathrm{L}$ diperlihatkan oleh jenis mangrove B. gymnorrhiza dari Luwu Timur, C. tagal dari Pangkep, dan E. agalocha dari Maros selebihnya memiliki MIC 100 dan $1.000 \mathrm{mg} / \mathrm{L}$ (Tabel 2). Secara umum bagian tanaman yang memiliki MIC paling rendah terdapat pada daun, kulit batang, dan akar.

Hasil penelitian ini menunjukkan bahwa mangrove yang dianalisis memiliki aktivitas anti bakteri $V$. harveyi yang sangat kuat dan sedang di mana nilai MIC berkisar $0,1 \mathrm{mg} / \mathrm{L}-1.000 \mathrm{mg} / \mathrm{L}$, kecuali $R$. apiculata dan $R$. mucronata dari Kabupaten Pangkep memiliki aktivitas antibakteri yang tergolong rendah dengan nilai MIC $10.000 \mathrm{mg} / \mathrm{L}$. Ramesh et al. (2014) melaporkan bahwa nilai MIC Acanthus ilicifolius terhadap $V$. harveyi adalah $125 \mu \mathrm{g} / \mathrm{mL}$. Semakin rendah nilai MIC suatu bahan aktif maka efektivitas bahan tersebut semakin tinggi, demikian pula sebaliknya. Menurut Abed et al. (2013), bahwa bahan antibakteri dikatakan memiliki daya hambat yang kuat jika nilai MIC adalah $500 \mu \mathrm{g} / \mathrm{mL}(500 \mathrm{mg} / \mathrm{L})$, daya hambat sedang 
Tabel 2. Hasil uji Minimum Inhibition Concentration (MIC) herbal mangrove yang berasal dari beberapa lokasi

Table 2. Minimum Inhibition Concentration (MIC) test result of herbal mangrove from several locations

\begin{tabular}{|c|c|c|c|}
\hline $\begin{array}{l}\text { Jenis herbal } \\
\text { Kind of herbal }\end{array}$ & $\begin{array}{c}\text { Asal } \\
\text { Source }\end{array}$ & $\begin{array}{c}\text { Aktivitas anti } \\
\text { bakteri } \text { V. harveyi } \\
\text { Antibacteri } \\
\text { V. harveyi activity }\end{array}$ & $\begin{array}{c}\text { Konsentrasi hambat } \\
\text { minimal (KHM) } \\
\text { Minimum inhibition } \\
\text { concentration (MIC) (mg/L) }\end{array}$ \\
\hline Acrosticium aureum & Maros & Negatif (Negative) & - \\
\hline Avicenia alba & Pangkep & Positif (Positive) & 1,000 \\
\hline Avicenia alba & Bone & Negatif (Negative) & - \\
\hline Avicenia lanata & Pangkep & Positif (Positive ) & 1,000 \\
\hline Avicenia lanata & Luwu Timur & Positif (Positive ) & 1,000 \\
\hline Avicenia marina & Bone & Negatif (Negative) & - \\
\hline Avicenia officinalis & Maros & Negatif (Negative) & - \\
\hline Bruguiera gymnorrhiza & Pangkep & Positif (Positive) & 1 \\
\hline Bruguiera gymnorrhiza & Luwu Timur & Positif (Positive) & 10 \\
\hline Ceriops tagal & Pangkep & Positif (Positive) & 10 \\
\hline Exoecaria agalocha & Maros & Positif (Positive) & 10 \\
\hline Nipah & Pangkep & Negatif (Negative) & - \\
\hline Rhizophora apiculata & Pangkep & Positif (Positive ) & 10,000 \\
\hline Rhizophora lamarckii & Takalar & Positif (Positive ) & 10 \\
\hline Rhizophora mucronata & Maros & Positif (Positive ) & 100 \\
\hline Rhizophora mucronata & Pangkep & Positif (Positive) & 10,000 \\
\hline Rhizophora mucronata & Bone & Positif (Positive ) & 1 \\
\hline Sonneratia alba & Maros & Positif (Positive ) & 1 \\
\hline Sonneratia alba & Bone & Positif (Positive ) & 100 \\
\hline Sonneratia caseolaris & Maros & Positif (Positive) & 1 \\
\hline Sonneratia lanceolata & Pangkep & Positif (Positive) & 0.1 \\
\hline Sonneratia ovata & Bone & Positif (Positive) & 100 \\
\hline Xylocarpus granatum & Luwu Timur & Positif (Positive) & 10 \\
\hline Xylocarpus granatum & Bone & Positif (Positive) & 10 \\
\hline Xylocarpus moluccensis & Bone & Positif (Positive) & 10 \\
\hline
\end{tabular}

jika nilai MIC 600-1.500 $\mu \mathrm{g} / \mathrm{mL}(600 \mathrm{mg} / \mathrm{L}-1.500 \mathrm{mg} /$ $\mathrm{L})$, daya hambat rendah jika nilai MIC lebih besar dari $1.600 \mu \mathrm{g} / \mathrm{mL}$ (8 $1.600 \mathrm{mg} / \mathrm{L})$.

\section{Uji Tantang Secara In Vitro dengan V. harveyi}

Hasil uji tantang secara in vitro dari S. lanceolata, S. alba, S. caseolaris, serta B. gymnorrhiza disajikan pada Gambar 3. Pada Gambar 3 terlihat bahwa setelah 24 jam, tidak ada pertumbuhan bakteri $V$. harveyi yang diberi ekstrak mangrove $S$. alba dan S. caseolaris pada konsentrasi $10.000 \mathrm{mg} / \mathrm{L}$. Hal ini menunjukkan bahwa pada konsentrasi $10.000 \mathrm{mg} / \mathrm{L}$, ekstrak metanol kedua jenis mangrove tersebut mematikan $V$. harveyi. Konsentrasi $V$. harveyi yang diberi ekstrak $S$. lanceolata dan B. gymnorrhiza pada konsentrasi yang sama $(10.000 \mathrm{mg} / \mathrm{L})$ masing-masing menunjukkan nilai yang masih tinggi yaitu $1,91 \times 10^{6} \mathrm{cfu} / \mathrm{mL}$ dan 9,55 x $10^{7} \mathrm{cfu} / \mathrm{mL}$. Secara umum, penggunaan ekstrak ma- ngrove memberikan konsentrasi $V$. harveyi yang lebih rendah dibandingkan dengan kontrol (tanpa pemberian ekstrak herbal mangrove).

\section{Hasil Uji Ambang Bawah dan Ambang Atas} Ekstrak Mangrove terhadap Benur Windu

Uji ambang bawah dan ambang atas ekstrak mangrove terhadap benur windu uji dilakukan untuk mengetahui toleransi benur udang windu terhadap dosis terendah dan tertinggi terhadap ekstrak mangrove S. lanceolata, S. alba, S. caseolaris, serta B. gymnorrhiza. Konsentrasi yang digunakan pada penelitian adalah sama dengan konsentrasi pada uji tantang secara in vitro yaitu $1 \mathrm{mg} / \mathrm{L}, 10 \mathrm{mg} / \mathrm{L}, 100 \mathrm{mg} / \mathrm{L}, 1.000$ $\mathrm{mg} / \mathrm{L}, 10.000 \mathrm{mg} / \mathrm{L}$, dan kontrol negatif (tanpa pemberian ekstrak mangrove). Hasil uji ambang bawah dan ambang atas ekstrak mangrove yang dapat ditolerir oleh benur udang windu disajikan pada Tabel 3. Pada 


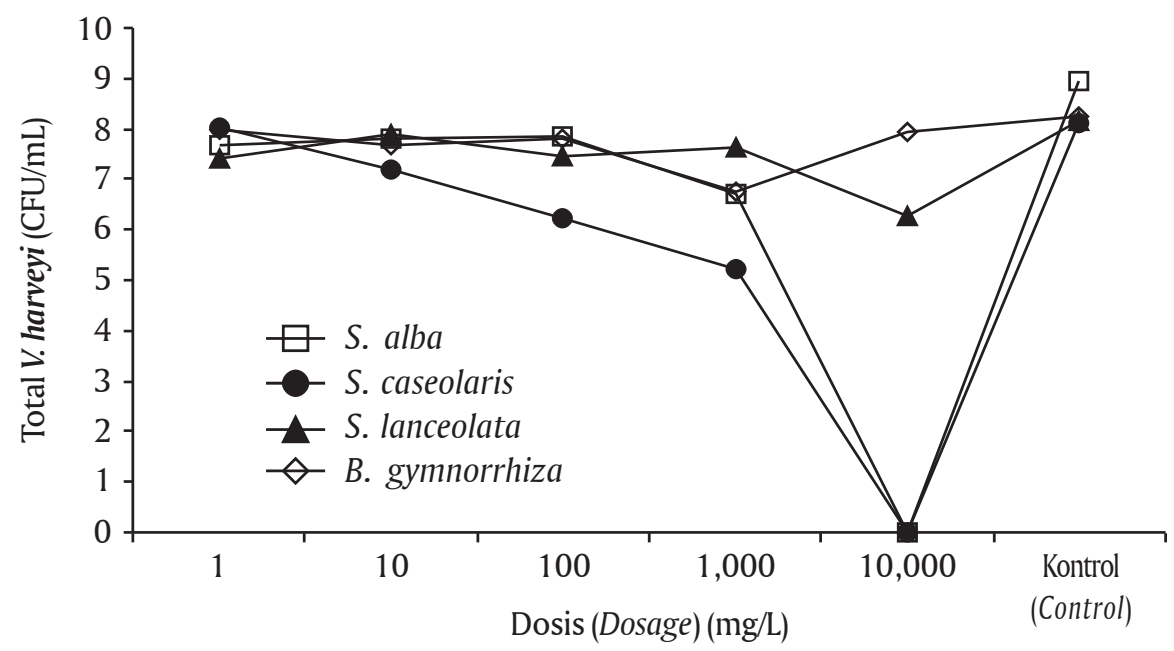

Gambar 3. Populasi $V$. harveyi setelah 24 uji tantang secara in vitro dengan ekstrak metanol herbal mangrove

Figure 3. $\quad$ V. harveyi population after 24 hours in vitro challenge with methanol extract of mangrove herbs

Tabel 3. Hasil uji toksisitas ekstrak metanol herbal mangrove terhadap larva udang windu pada konsentrasi yang berbeda

Table 3. Toxicity test result of methanol extracted of mangrove herbs on tiger shrimp post larvae at different concentrations

\begin{tabular}{lcccc}
\hline \multirow{2}{*}{$\begin{array}{c}\text { Konsentrasi } \\
\text { Concentrations }\end{array}$} & \multicolumn{3}{c}{$\begin{array}{c}\text { Mortalitas larva udang windu setelah 96 jam } \\
\text { Black tiger shrimp post larvae mortality after } 96 \text { hours (\%) }\end{array}$} \\
\cline { 2 - 5 } & S. alba & S. lanceolata & B. gymnorrihza & S. caseolaris \\
\hline $1 \mathrm{mg} / \mathrm{L}$ & 12.22 & 4.44 & 13.33 & 13.33 \\
$10 \mathrm{mg} / \mathrm{L}$ & 12.22 & 14.44 & 5.55 & 13.33 \\
$100 \mathrm{mg} / \mathrm{L}$ & 17.78 & 16.67 & 18.89 & 8.89 \\
$1,000 \mathrm{mg} / \mathrm{L}$ & 31.11 & 16.67 & 95.56 & 26.67 \\
$10,000 \mathrm{mg} / \mathrm{L}$ & 100 & 100 & 100 & 100 \\
Kontrol (tanpa ekstrak mangrove) & 17.78 & 17.78 & 17.78 & 17.78 \\
Control (without mangrove extract) & & & & \\
\hline
\end{tabular}

Tabel 3 terlihat bahwa pada konsentrasi $10.000 \mathrm{mg} / \mathrm{L}$ dari semua ekstrak mangrove tidak dapat lagi ditolerir oleh benur udang windu, pada konsentrasi tersebut mortalitas udang windu mencapai $100 \%$ setelah 96 jam. Pada konsentrasi 1.000 mg/L, mortalitas tertinggi terlihat pada penggunaan ekstrak mangrove $B$. gymnorrihza yaitu $95,56 \%$; berturut-turut $S$. alba $(31,11 \%)$, S. caseolaris $(26,67 \%)$, dan terendah pada ekstrak mangrove $S$. lanceolata yaitu 16,67\%. Melki et al. (2011) melaporkan bahwa mortalitas Artemia pada konsentrasi $1.000 \mathrm{mg} / \mathrm{L}$ ekstrak daun S. alba sebesar 53,33\%.

Pada konsentrasi $100 \mathrm{mg} / \mathrm{L}$, mortalitas tertinggi kembali diperlihatkan oleh ekstrak mangrove $B$. gymnorrihza yaitu $18,89 \%$ dan terendah oleh ekstrak mangrove $S$. caseolaris yaitu $8,89 \%$. Sebaliknya, pada kon- sentrasi $10 \mathrm{mg} / \mathrm{L}$ mortalitas larva udang tertinggi pada perlakuan yang menggunakan ekstrak mangrove S. lanceolata yaitu $14,44 \%$ dan terendah pada perlakuan yang menggunakan ekstrak $B$. gymnorrihza yaitu $5,55 \%$; sedangkan pada perlakuan dengan konsentrasi $1 \mathrm{mg} / \mathrm{L}$, mortalitas udang windu tertinggi kembali diperlihatkan oleh perlakuan yang menggunakan ekstrak mangrove $B$. gymnorrihza, S. caseolaris yaitu dengan tingkat mortalitas $13,33 \%$ dan terendah pada perlakuan yang menggunakan ekstrak mangrove $S$. gulngai yaitu $4,44 \%$. Hal ini menunjukkan bahwa dosis ambang atas yang masih bisa ditolerir (tidak bersifat toksik) oleh benur udang windu adalah 10.000 $\mathrm{mg} / \mathrm{L}$.

Hasil penelitian ini menunjukkan bahwa semakin tinggi konsentrasi ekstrak mangrove, maka mortali- 
tas udang semakin tinggi. Hal serupa dilaporkan oleh Melki et al. (2011) bahwa semakin tinggi konsentrasi ekstrak $S$. alba maka semakin toksik terhadap Artemia, hal ini dapat dilihat dari tingkat mortalitas yang semakin tinggi seiring dengan peningkatan konsentrasi yaitu berturut-turut 3,33\% pada konsentrasi 10 $\mu \mathrm{g} / \mathrm{mL}(10 \mathrm{mg} / \mathrm{L}) ; 10 \%$ pada konsentrasi $100 \mu \mathrm{g} / \mathrm{mL}$; 13,33\% pada konsentrasi $200 \mu \mathrm{g} / \mathrm{mL} ; 34,33 \%$ pada konsentrasi $500 \mu \mathrm{g} / \mathrm{mL}$; dan 53,33\% pada konsentrasi $1.000 \mu \mathrm{g} / \mathrm{mL}$. Toksisitas ekstrak mangrove yang digunakan pada penelitian ini jauh lebih kecil jika dibanding dengan toksisitas ekstrak mangrove R. mucronata terhadap Artemia. Howlader et al. (2013) melaporkan bahwa ekstrak etahnol dari $R$. mucronata mematikan 50\% larva Artemia pada konsentrasi 0,5 mg/L setelah 24 jam.

\section{KESIMPULAN}

Ekstrak herbal mangrove menunjukkan positif mengandung anti bakteri Vibrio harveyi 65,91\% dengan daya hambat tertinggi pada $S$. lanceolata dengan nilai MIC 0,1 mg/L. Sementara, pada S. alba, S. caseolaris, B. gymnorrhiza, R. mucronata mempunyai nilai MIC masing-masing $1 \mathrm{mg} / \mathrm{L}$. Pada konsentrasi 10.000 $\mathrm{mg} / \mathrm{L}$ dari ekstrak S. lanceolata, S. alba, S. caseolaris, dan B. gymnorrhiza sudah bersifat toksik terhadap benur udang windu dengan mortalitas mencapai $100 \%$ setelah 96 jam.

\section{UCAPAN TERIMA KASIH}

Terima kasih atas bimbingan Bapak Ir. Muharijadi Atmomarsono, sebagai Kepala Kelti Patologi, dan rekan-rekan peneliti dan teknisi yang penuh dedikasi dan tanggung jawab membantu terlaksananya penelitian ini. Penelitian ini dibiayai dari dana DIPA BPPBAP Maros tahun 2013.

\section{DAFTAR ACUAN}

Abed, S.A., Sirat, H.M., \& Taher, M. (2013). Total phenolic, antioxidant, antimicrobial activities and toxicity study of Gynotroches axillaris blume (Rhizophoraceae). EXCLI Journal, 12, 404-412.

Ahilan, B., Nithiyapriyatharshini, A., \& Ravaneshwaran, K. (2010). Influence of certain herbal additives on the growth, survival, and disease resistance of goldfish, Carassius auratus (linnaeus). Tamilnadu J. Veterinary \& Animal Sciences, 6(1), 5-11.

Arivuselvan, N., Jagadeesan, D., Govindan, T., Khatiresan, K., \& Anantharaman, T. (2011). In vitro antibacterial activity of leaf and bark extracts of selected mangroves against fish and shrimp pathogens. Global Journal of Pharmacology, 5(2), 112-116.

Babuselvam, M., Farook, K.A.M., Abideen, S., Mohamed, M.P., \& Uthiraselvam, M. (2012). Screen- ing of antibacterial activity of mangrove plant extract against fish and shrimp patogens. International Journal of Applied Miocrobiology Science, 1(3), 20-25.

Baskaran, R., \& Mohan, P.M. (2012). In vitro antibacterial activity of leaf extracts of Rhizophora mucronata L. against multi drug resisten Vibrio spp. isolated from marine water lobster's larvae hatcheries. Indian Journal of Geo-Marine Science, 41(3), 218222.

Chakraborty, S., \& Ghosh, U. (2013a). Pharmaceutical and phytochemical evaluation of a novel antiwhite spot syndrome virus drug derived from marine plants. International Journal of Natural Products Research, 3(4), 82-91.

Chakraborty, S., \& Ghosh, U. (2013b). In vivo biochemical changes occurring at different time intervals in white spot syndrome virus infected shrimp, treated with anti-WSSV drug drived from marine plants. J. App. Pharm. Sci., 3(11), 059-069.

Chakraborty, S., \& Ghosh, U. (2014). In vivo immunological changes occurring at different time intervals in white spot syndrome virus infected shrimp, treated with anti-WSSV drug drived from marine plants. International Journal of Basic and Applied Virology, 3(1), 01-15.

Chakraborty, S., Ghosh, U., Balasubramanian, T., \& Das, P. (2014). Screening, isolation and optimization of anti-white spot syndrome virus drug derived from marine plants. Asian Pacific Journal of Tropical Biomedicine, p. S107-S117.

Dhayanithi, N.B., Kumar, T.T.A., Balasubramanian, T., \& Tissera, K. (2013). A study on the effect of using mangrove leaf extracts as a feed additive in the progress of bacterial infections in marine ornamental fish. Journal of Coastal Life Medicine, 1(3), 217-224.

Ganju, K.P.M.L., Sairam, M., Banerjee, P.K., \& Sawhney, R.C. (2008). A review of high throughput technology for the screening of natural products. Biomedicine and Pharmacotherapy, p. 6294-98.

Govind, P., Madhuri, S., \& Mandloi, A.K. (2012). Immunostimulant effect of medical plants on fish. IRJP, 3(3), 112-114.

Howlader, M.S.I., Ahmed, M.J., Kabir, A.N.M.H., Uddin, M.G., \& Hossain, M.K. 2013. Antibacterial, cytotoxic, analgesic, and diuretic activities of Rhizophora mucronata Lam. Bark. Indian Journal of Natural Products and Resource, 4(3), 229-232.

Kadriah, I.A.K. (2012). Pengembangan metode deteksi cepat vibrio berpendar pada udang penaeid. Disertasi. Institut Pertanian Bogor. Bogor, $126 \mathrm{hlm}$.

Kannapiran, E., Ravindran, J., Chandrasekar, R., \& Kalalarasi, A. (2009). Studies on luminous, Vibrio 
harveyi associated with shrimp culture system rearing Penaeus monodon. J. Environ. Biol. 30(5), 791-795.

Kasanah, N., \& Isnansetyo, A. (2013). High throughput screening dan bioassay dalam penemuan senyawa bioaktif dari alam. Materi Workshop dan Pelatihan Bioprospekting Bahan Alam Kelautan II. Laboratorium Hidrobiologi. Jurusan Perikanan. Fakultas Pertanian. Universitas Gadjah Mada. Jogjakarta, 22 hlm.

Karuppusamy, S., \& Rajsekaran, K.M. (2009). High throughput antibacterial screening of plant extracts by resazurin redox with special reference to medical plant of Western Ghats. Global Journal of Pharmacology, 3(2), 63-68.

Kitamura, S., Anwar, C., Chaniago, A., \& Baba, S. (1998). Handbook of mangrove in Indonesia, Bali \& Lombok. 58 pp.

Laith, A.A., \& Najiah, M. (2014). Antimocrobial activities of blinding tree, Excoecaria agallocha against selected bacterial pathogens. Journal of Microbiology and Antimocrobial, 6(2), 29-3.

Langfield, R.D., Scarano, F.J., Heitzman, M.E., Konodo, M., Hammond, G.B., \& Neto, C.C. (2004). Use of modified microplate bioassay method to investigate antibacterial activity in the Peruvian medicinal plant Peperomia galioides. Journal of Ethnophrmacology, 94, 279-281.

Melki, S.D., Effendi, H., \& Mustopa, A.Z. (2011). Biopotensi tumbuhan mangrove untuk pencegahan penyakit vibriosis pada udang windu. Maspari Journal, 02, 39-47.

Millon, M.A., Muhit, M.A., Goshwami, D., Masud, M.M., \& Begum, B. (2012). Antioxidant, cytotoxic, and antimicrobial activity of Sonneratia alba bark. IJPSR, 3(7), 2233-2237.

Mouafi, F.E., Abdel-Aziz, S.M., Bashir, A.A., \& Fyiad, A.A. (2014). Phytochemical analysis and antimicrobial activity of mangrove leaves (Avicenna marina and Rhizophora stylosa) against some pathogens. World Applied Sciences Journal, 29(4), 547-554.

Muliani, Nurbaya, \& Suryati, E. (2013). Potensi tanaman asosiasi mangrove sebagai penghasil antibakteri penyebab penyakit pada udang windu (Penaeus monodon). hlm. 193-201 Dalam Sudrajat, A., Masengi, S., Nainggolan, C., Raharjo, P., \& Sipahutas, Y.H (Eds.), Prosiding Seminar Nasional Perikanan Indonesia. Hasil Penelitian Perikanan dan
Kelautan Tahun 2013. Pusat Penelitian dan Pengabdian Masyarakat, Sekolah Tinggi Perikanan. Badan Pengembangan Sumber Daya Manusia Kelautan dan Perikanan. Kementerian Kelautan dan Perikanan.

Mulyani, Y., Bachtiar, E., \& Kurnia, A.M.U. (2013). Peranan senyawa metabolit sekunder tumbuhan mangrove terhadap infeksi bakteri Aeromonas hydrophila pada ikan mas (Cyprinus carpio L). Universitas Padjajaran. Bandung. Jurnal Akuatika, 4(1), 1-9.

Noor, Y.R., Khazali, M., \& Suryadiputra, I N.N. (2006). Panduan pengenalan mangrove di Indonesia. Ditjen. PHKA. Wetlands International-Indonesia Programme, $220 \mathrm{hlm}$.

Ramesh, K., Natarajan, M., \& Sridhar, H. (2014). Antvibrio activity of mangrove and mangrove assosiates on shrimp pathogen, Vibrio harveyi VSH5. Global Veterinaria, 12(2), 270-276.

Sahu, K.S., Kathiresan, K., Sing, R., \& Senthilraja, P. (2012). Molecular docking analyses of Avicenia marina derived phytochemicals against white spot syndrome virus (WSSV) envelope protein-VP28. Bioinformation, 8(8), 897-900.

Shamsuddin, A.A., Najiah, M., Suvik, A., Azariyah, M.N., Kamaruzzaman, B.Y., Effendy, A.W., \& John, B.A. (2013). Antibacterial properties of selected mangrove plants against Vibrio species and its cytotoxicity against Artemia salina. World Applied Sciences Journal, 25(2), 333-340.

Shelar, P.S., Reddy, V.K., Shelar, G.S., \& Reddy, G.V.S 2012. Medicinal value of mangroves and its antimicrobial properties-a review. Continental J. Fisheries and Aquatic Science, 6(1), 26-37.

Suryati, E., Rosmiati, \& Tenrulo, A. (2007). Penanggulangan penyakit bakteri pada udang windu (Penaeus monodon) menggunakan bioaktif tanaman mangrove Avicenia alba. Marina Chimica Acta, 2(2), 19-23.

Turker, H., Yildirim, A.B., \& Karakas, F.P. (2009). Sensitivity of bacteria isolated from fish to some medicinal plant. Turkish Journal of Fisheries and Aquatic Sciences, 9, 181-186.

Wang, H., Cheng, H., Wang, F., Wei, D., \& Wang, X. (2010). An improved 3-(4,5-dimethylthiazol-2-yl)2,5-diphenyl tetrazolium bromide (MTT) reduction assay for evaluating the viability of Escherichia coli cells. Journal of Microbilogical Methods, 82, 330-333. 